\title{
Article \\ Effect of Different Tillage Systems on Soil Organic Carbon and Enzymatic Activity
}

\author{
Małgorzata Szostek 1,*(D), Ewa Szpunar-Krok ${ }^{2} \mathbb{D}$, Renata Pawlak $^{2}$, Jadwiga Stanek-Tarkowska ${ }^{1} \mathbb{D}$ \\ and Anna Ilek ${ }^{3}$ (D)
}

check for updates

Citation: Szostek, M.; Szpunar-Krok, E.; Pawlak, R.; Stanek-Tarkowska, J.; Ilek, A. Effect of Different Tillage Systems on Soil Organic Carbon and Enzymatic Activity. Agronomy 2022, 12, 208. https://doi.org/10.3390/ agronomy12010208

Academic Editor: Hailin Zhang

Received: 12 December 2021

Accepted: 14 January 2022

Published: 15 January 2022

Publisher's Note: MDPI stays neutral with regard to jurisdictional claims in published maps and institutional affiliations.

Copyright: (C) 2022 by the authors. Licensee MDPI, Basel, Switzerland. This article is an open access article distributed under the terms and conditions of the Creative Commons Attribution (CC BY) license (https:// creativecommons.org/licenses/by/ $4.0 /)$.
1 Department of Soil Science, Environmental Chemistry and Hydrology, College of Natural Sciences, University of Rzeszów, Zelwerowicza 8b, 35-601 Rzeszów, Poland; jstanek@ur.edu.pl

2 Department of Plant Production, College of Natural Sciences, University of Rzeszów, Zelwerowicza 4, 35-601 Rzeszów, Poland; szpunar-krok@wp.pl (E.S.-K.); pawlak_renata@o2.pl (R.P.)

3 Department of Botany and Forest Habitats, Faculty of Forestry and Wood Technology, Poznań University of Life Sciences, Wojska Polskiego 71f, 60-625 Poznań, Poland; anna.ilek@up.poznan.pl

* Correspondence: mszostek@ur.edu.pl; Tel.: +48-177854832

\begin{abstract}
The aim of the study was to compare the effect of conventional, simplified, and organic farming systems on changes in the content of soil organic carbon, organic matter fractions, total nitrogen, and the enzymatic activity. The research was conducted from 2016-2018 on arable land in the south-eastern part of Poland. The selected soils were cultivated in conventional tillage (C_Ts), simplified tillage (S_Ts), and organic farming (O_Fs) systems. The analyses were performed in soil from the soil surface layers (up to $25 \mathrm{~cm}$ depth) of the experimental plots. The highest mean contents of soil organic carbon, total nitrogen, and organic matter fractions were determined in soils subjected to the simplified tillage system throughout the experimental period. During the study period, organic carbon concentration on surface soil layers under simplified tillage systems was 31 and 127\% higher than the soil under conventional tillage systems and organic farming systems, respectively. Also, the total nitrogen concentration in those soils was more than $40 \%$ and $120 \%$ higher than conventional tillage systems and organic farming systems, respectively. Moreover, these soils were characterised by a progressive decline in SOC and Nt resources over the study years. There was no significant effect of the analysed tillage systems on the $\mathrm{C}: \mathrm{N}$ ratio. The tillage systems induced significant differences in the activity of the analysed soil enzymes, i.e., dehydrogenase (DH) and catalase (CAT). The highest DH activity throughout the experiment was recorded in the O_Fs soils, and the mean value of this parameter was in the range of $6.01-6.11 \mu \mathrm{mol} \mathrm{TPF} \cdot \mathrm{kg}^{-1} \cdot \mathrm{h}^{-1}$. There were no significant differences in the CAT values between the variants of the experiment. The results confirm that, regardless of other treatments, such as the use of organic fertilisers, tillage has a negative impact on the content of SOC and organic matter fractions in the O_Fs system. All simplifications in tillage reducing the interference with the soil surface layer and the use of organic fertilisers contribute to improvement of soil properties and enhancement of biological activity, which helps to maintain its productivity and fertility.
\end{abstract}

Keywords: tillage systems; organic farming; dehydrogenase activity; catalase activity; fractions of soil organic matter

\section{Introduction}

The tillage system consists of processes modifying the physical, chemical, and biological properties of soils. Soil cultivation is aimed at creation of appropriate conditions for the growth and development of crops, which are directly reflected in their yields. Cultivation practices have an effect on soil water retention capacity, temperature, aeration, and the rate of decomposition of crop residues [1,2]. The choice of an appropriate tillage system is mainly dependent on the local soil conditions, climate, and type of crops [3]. The 
application of suitable agricultural technological practices in arable land has an impact on soil productivity and fertility [4]. The progressive degradation of the soil environment caused by the use of heavy machinery and agricultural tools together with the intensified chemisation of agriculture necessitate the search for soil cultivation methods ensuring soil protection and restoration of natural biocoenoses, especially in areas with intensive agricultural production [5-7].

The oldest and most widespread tillage method (also in Poland) is the plough tillage system, also known as traditional or conventional ploughing. This system is based mainly on the application of the plough, which results in cutting and turning the top layer of soil $[7,8]$. This tillage system is labour-intensive and energy-consuming, as it also requires additional operations, e.g., harrowing or rolling. An undoubted advantage of the conventional tillage system is the adequate soil loosening and aeration, which creates more favourable conditions for the growth and development of crops. Nevertheless, conventional tillage exerts many adverse effects, as it contributes to excessive compaction of soils, higher susceptibility of soils to erosion, and accelerated organic matter mineralisation $[2,5,9,10]$. Consequently, long-term conventional tillage may cause loss of soil productivity and fertility [11]. An alternative tillage method is the simplified (no-till) tillage. Through minimisation or exclusion of certain agrotechnical treatments, this system helps to reduce the negative impact of agricultural activity on the soil environment. In the simplified tillage system, plant residues left in the field protect the soil and reduce erosive processes substantially. The use of plant residues in combination with minimal soil interference creates favourable conditions for the development of soil organisms and protects organic matter against accelerated mineralisation [1,2,5,12-14]. Measures for the maintenance and protection of soil fertility are also undertaken in the so-called organic farming system, which is a counteraction to the intensification of agriculture, especially to the excessive use of fertilisers and plant protection products [10,15-17]. The organic agriculture practices contribute to enhancement of the biological activity of soils, which is mainly achieved through an increase in the organic matter content. The increased organic matter content in soils from the organic system is the result of the use of catch crops, recycling of crop residues, application of natural fertilisers (including manure), and simplification of such agrotechnical procedures as ploughing $[15,18,19]$. The impact of various tillage systems on the physical, chemical, and biological properties of soil has been extensively investigated and documented in the literature. The available data show that the abundance of organic matter in the top layer of arable soils is substantially higher in the organic farming system than in the conventional system. Greater organic matter abundance in soils enhances the biological and biochemical activity of soils, increases biodiversity, provides suitable conditions for the growth and development of crops, and protects soils against erosion [10,11,14,16,19-25]. The management of the agricultural production space often increasingly requires measures for protection of soil organic matter, which is also one of the key objectives of EU policy [26]. The common agrotechnical treatments, especially monoculture or improper fertilisation used in intensive agriculture, intensify the mineralisation processes and the loss of humus accumulated in the soil. In addition to productivity loss, this increases the release of $\mathrm{CO}_{2}$ into the atmosphere, thus contributing to climate change [27-29]. To estimate the impact of agricultural activity on the quantity and quality of soil organic matter, the total organic carbon content and the levels of soil organic matter fractions are determined. Humified organic matter, which is conventionally divided into humic acids $\left(\mathrm{C}_{\mathrm{HAs}}\right)$, fulvic acids $\left(\mathrm{C}_{\mathrm{FAs}}\right)$, and humins $\left(\mathrm{C}_{\mathrm{H}}\right)$, is the microbiologically most stable reservoir of organic matter $[13,30]$.

Enzymatic activity, i.e., a sensitive indicator of changes caused by various factors, is one of the elements in the assessment of soil environment fertility. Soil enzymes are the basic determinants of processes taking place in soil. They are natural mediators and catalysts in many important processes, e.g., the decomposition of organic matter or the flow of carbon, nitrogen, and other elements necessary for the proper growth and development of plants. Knowledge of the enzymatic activity and other soil properties can help to precisely estimate the impact of applied farming treatments on soil fertility and productivity. Given their role 
in the environment, oxidoreductases (including dehydrogenases and catalases) are regarded as the most important enzymes, as they are directly involved in the biogeochemical carbon, nitrogen, phosphorus, and sulphur cycle in soils $[4,31,32]$.

The aim of the research was to assess the variability of selected soil parameters (soil organic carbon, total nitrogen, fractions of soil organic matter, and enzyme activity) in private farms. These soils were used in a manner not imposed by the authors, and kept the burrows as defined by the farmers-conventional tillage systems, simplified tillage systems, and the organic farming system. Most research on the influence of different tillage systems on soil properties is based on strict field experiments with a known system of experimental factors $[6,9,15]$. In our research, we worked closely with farmers, and the obtained results allowed us to estimate the changes in selected soil properties under specific farming conditions.

\section{Materials and Methods}

\subsection{Study Area and Sampling}

The study was carried out on selected plots of arable land in the south-eastern part of Poland (Podkarpackie Province) from 2016-2018. The location of the study area is shown in Figure 1.

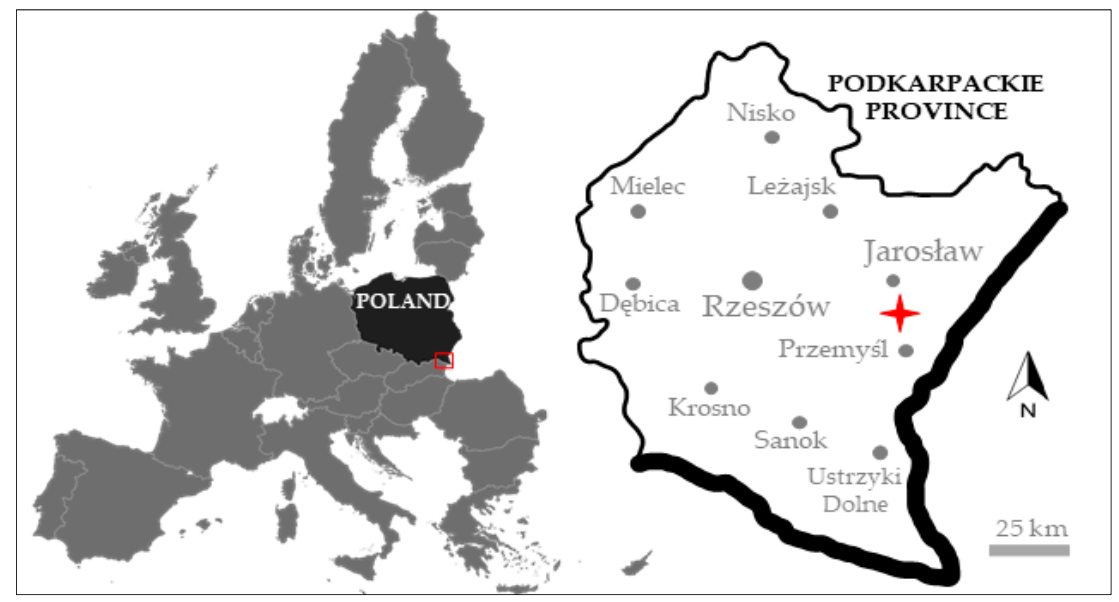

Figure 1. Location of the study area.

The arable land plots selected for the analyses were located in areas with similar physiographic, hydrological, and climatic conditions. The soil in the plots had a similar granulometric composition. Three groups of arable land (each with 6 plots) were selected for the study. They differed in the cultivation treatments, crop structure, and the type and doses of fertilisation with basic plant nutrients-NPK. The following experimental variants were established: C_Ts - soils subjected to the conventional (ploughing) system, S_Ts_simplified system, and O_Fs_-soils subjected to ploughing in the organic farming system. Detailed data on the agrotechnical treatments applied in each year of the experiment and on the doses of the basic plant nutrients (NPK) supplied with the fertilisation are summarised in Table 1. Figure 2 shows the structure of crops cultivated during the study in each research plot.

\subsection{Determination of Soil Properties}

Soil samples intended for the analysis of the soil properties were collected from the topsoil up to a depth of $25 \mathrm{~cm}$. They were collected after plant harvesting in each study year. The particle size distribution in air-dry samples sieved through a 2-mm mesh sieve was determined with the laser diffraction method (Analysette 22, Fritsch, Idar-Oberstein, Germany). The $\mathrm{pH}$ value was determined in a 1:2.5 substrate-water suspension using a 4221 pH-meter (Hanna Instruments, Nusfalau, Romania). Electrical conductivity (EC) was analysed in a 1:5 substrate-water suspension with a HI 2316 EC-meter from Hanna 
Instruments (Nusfalau, Romania). The total nitrogen content $(\mathrm{Nt})$ was determined with the Kjeldahl method. Soil organic carbon (SOC) was determined using the Walkley-Black procedure [33]. The C:N ratio was calculated based on the SOC and Nt contents. The fractional composition of soil humus was determined in air-dry soil samples using the Kononowa-Bielczikowa method by extraction of fractions with a mixture of $1 \mathrm{M} \mathrm{NaOH}$ and $\mathrm{Na}_{4} \mathrm{P}_{5} \mathrm{O}_{7}$. The fractionation was performed to determine the following humified organic matter fractions: humic acids $\left(\mathrm{C}_{\mathrm{HAs}}\right)$, fulvic acids $\left(\mathrm{C}_{\mathrm{FAs}}\right)$, and humins $\left(\mathrm{C}_{\mathrm{H}}\right)$. Based on content of the $\mathrm{C}_{\mathrm{HAs}}$ and $\mathrm{C}_{\mathrm{FAs}}$, the $\mathrm{C}_{\mathrm{HAs}} / \mathrm{C}_{\mathrm{Fas}}$ ratio was calculated [30,34].

Table 1. Crop rotation, fertilisation, and cultivation treatments used in the study.

\begin{tabular}{|c|c|c|c|c|c|c|c|}
\hline \multirow[t]{2}{*}{ Tillage System } & \multirow[t]{2}{*}{ Year } & \multirow[t]{2}{*}{ Cultivated Plants } & \multirow{2}{*}{$\begin{array}{l}\text { Types of } \\
\text { Fertilisers }\end{array}$} & \multicolumn{3}{|c|}{$\begin{array}{l}\text { Soil Fertilisation per Year } \\
\qquad\left(\mathrm{kg} \mathrm{ha}^{-1}\right)\end{array}$} & \multirow{2}{*}{$\begin{array}{c}\text { Cultivation Treatments and } \\
\text { Tillage Depth }(\mathrm{cm})\end{array}$} \\
\hline & & & & $\mathbf{N}$ & $\mathbf{P}$ & $\mathbf{K}$ & \\
\hline \multirow{10}{*}{$\mathrm{C}_{-} \mathrm{Ts}$} & \multirow{4}{*}{2016} & winter wheat & \multirow{4}{*}{ inorganic } & $146-150$ & $20-26$ & $60-75$ & \multirow{4}{*}{$\begin{array}{l}\text { Pre-sow ploughing }(18-22 \mathrm{~cm}) \\
\text { Cultivating and sowing unit } \\
\qquad(10-15 \mathrm{~cm})\end{array}$} \\
\hline & & winter rapeseed & & $150-190$ & 26 & 80 & \\
\hline & & soybean & & 15 & 22 & 63 & \\
\hline & & winter barley & & 130 & 26 & 75 & \\
\hline & \multirow[t]{3}{*}{2017} & maize & \multirow[t]{3}{*}{ inorganic } & 165 & 30 & 150 & $\begin{array}{l}\text { Disc harrow }(12-18 \mathrm{~cm}) \\
\text { Pre-winter ploughing }(25 \mathrm{~cm}) \\
\text { Cultivating and sowing unit } \\
\qquad(10-15 \mathrm{~cm})\end{array}$ \\
\hline & & winter wheat & & $138-155$ & 26 & 75 & \multirow{2}{*}{$\begin{array}{c}\text { Pre-sow ploughing }(18-22 \mathrm{~cm}) \\
\text { Cultivating and sowing unit } \\
(10-15 \mathrm{~cm})\end{array}$} \\
\hline & & winter rapeseed & & $160-220$ & 31 & 87 & \\
\hline & \multirow{3}{*}{2018} & maize & \multirow{3}{*}{ inorganic } & 155 & 22 & 212 & $\begin{array}{l}\text { Disc harrow }(12-18 \mathrm{~cm}) \\
\text { Pre-winter ploughing }(25-30 \mathrm{~cm}) \\
\text { Cultivating and sowing unit } \\
(10-15 \mathrm{~cm})\end{array}$ \\
\hline & & winter wheat & & 115-190 & $22-31$ & $63-87$ & $\begin{array}{l}\text { Pre-sow ploughing }(18-22 \mathrm{~cm}) \\
\text { Cultivating and sowing unit } \\
\qquad(10-15 \mathrm{~cm})\end{array}$ \\
\hline & & winter rapeseed & & 155 & 31 & 58 & \multirow{3}{*}{$\begin{array}{l}\text { Pre-sow ploughing }(18-22 \mathrm{~cm}) \\
\text { Cultivating and sowing unit } \\
\qquad(10-15 \mathrm{~cm})\end{array}$} \\
\hline \multirow{8}{*}{ S_Ts } & \multirow{3}{*}{2016} & winter wheat & \multirow{3}{*}{ inorganic } & 200 & 31 & 60 & \\
\hline & & winter rapeseed & & 195 & 31 & 60 & \\
\hline & & sugar beets & & $125-194$ & 31 & 60 & \multirow{6}{*}{$\begin{array}{l}\text { Disc harrow }(12-18 \mathrm{~cm}) \\
\text { Cultivating and sowing unit } \\
\qquad(10-15 \mathrm{~cm})\end{array}$} \\
\hline & \multirow{3}{*}{2017} & maize & \multirow{3}{*}{ inorganic } & 162 & 31 & 60 & \\
\hline & & winter wheat & & 210 & 31 & 60 & \\
\hline & & winter rapeseed & & 200 & 42 & 80 & \\
\hline & \multirow{2}{*}{2018} & winter wheat & \multirow{2}{*}{ inorganic } & $168-246$ & 31 & 75 & \\
\hline & & winter rapeseed & & 210 & 31 & 87 & \\
\hline \multirow{7}{*}{ O_Fs } & \multirow{3}{*}{2016} & potatoes & \multirow{3}{*}{ organic } & 94 & 25 & 95 & \multirow{2}{*}{$\begin{array}{l}\text { Pre-winter ploughing }(25-30 \mathrm{~cm}) \\
\text { Cultivation unit }(10-15 \mathrm{~cm})\end{array}$} \\
\hline & & winter wheat & & $94-118$ & $24-31$ & $108-135$ & \\
\hline & & winter rapeseed & & 160 & 44 & 166 & \multirow{3}{*}{$\begin{array}{l}\text { Pre-sow ploughing }(18-22 \mathrm{~cm}) \\
\text { Cultivating and sowing unit } \\
\qquad(10-15 \mathrm{~cm})\end{array}$} \\
\hline & \multirow{2}{*}{2017} & winter wheat & \multirow{2}{*}{ organic } & 118 & 31 & 135 & \\
\hline & & winter rapeseed & & 160 & 44 & 166 & \\
\hline & 2018 & potatoes & organic & 71-118 & $18-31$ & 81-135 & $\begin{array}{l}\text { Disc harrow }(12-18 \mathrm{~cm}) \\
\text { Pre-winter ploughing }(25-30 \mathrm{~cm}) \\
\text { Cultivation unit }(10-15 \mathrm{~cm})\end{array}$ \\
\hline & & winter wheat & & 141 & 37 & 162 & $\begin{array}{l}\text { Pre-sow ploughing }(18-22 \mathrm{~cm}) \\
\text { Cultivating and sowing unit } \\
\qquad(10-15 \mathrm{~cm})\end{array}$ \\
\hline
\end{tabular}




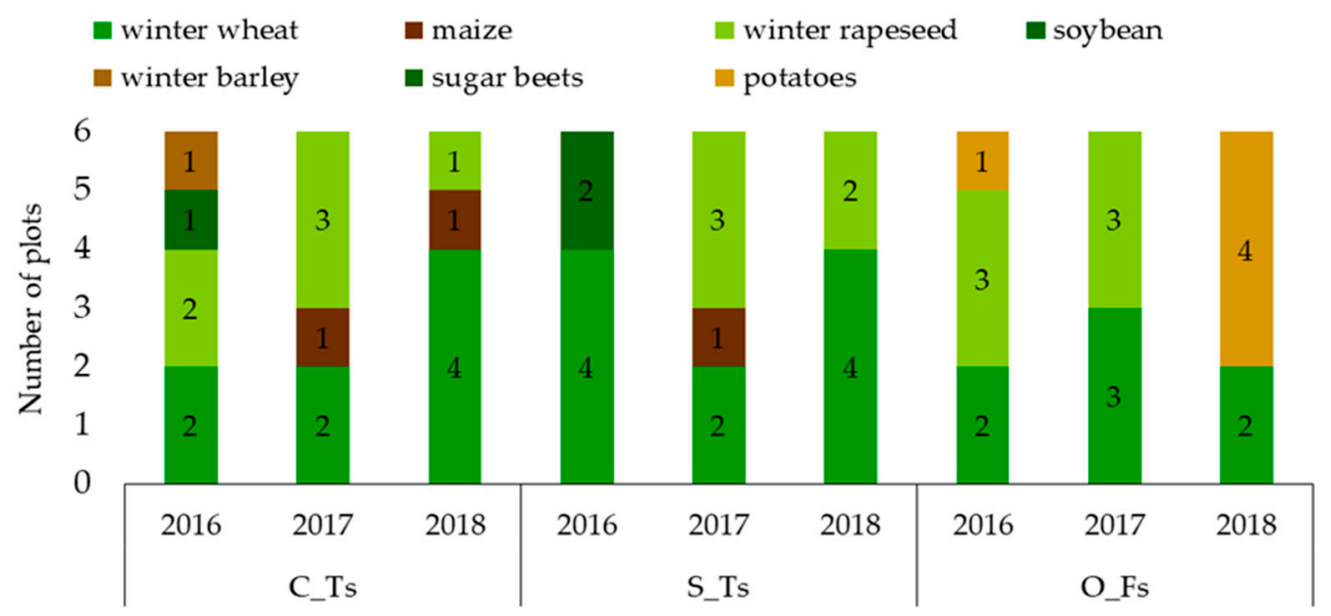

Figure 2. Plants cultivated on the experimental plots in the study years.

The activity of soil enzymes from the group of oxidoreductases, i.e., dehydrogenase (EC 1.1.1.1) and catalase, was determined in fresh soil samples with a natural moisture level. The dehydrogenase activity (DH) was determined with the use of the Lenhard method following the procedure proposed by Casida. It was determined by reduction of 2,3,5-tetrazolium chloride (TTC) to triphenyl formazan (TPF). To determine DH, an approx. 6-g aliquot of fresh soil was incubated with $1 \mathrm{~mL}$ of $3 \%$ TTC at $37^{\circ} \mathrm{C}$ for $24 \mathrm{~h}$. TPF was extracted using ethyl alcohol and analysed spectrophotometrically with a UV-Vis Schimadzu 2630 spectrophotometer. The activity of dehydrogenases (DH) was expressed in $\mu \mathrm{mol}$ of TPF $\mathrm{kg}^{-1} \mathrm{~h}^{-1}$ [35]. The catalase (CAT) activity was determined with the manganometric method according to the procedure proposed by Johnson and Temple [36]. Soil samples were incubated with the addition of hydrogen peroxide (a natural substrate of the enzyme). The $\mathrm{H}_{2} \mathrm{O}_{2}$ remaining in the soil and not decomposed by catalase was titrated with potassium permanganate in an acidic environment. The catalase activity was expressed in $\mu \mathrm{mol} \mathrm{H}_{2} \mathrm{O}_{2} \mathrm{~g}^{-1}$ d.w. $\mathrm{min}^{-1}$.

\subsection{Statistical Analysis}

All statistical analyses were performed using STATISTICA 13.3 software (StatSoft Inc., Tulsa, OK, USA). To show the existence of uniform groups of objects $(\alpha=0.05)$, the multiple comparison Tukey HSD test was performed following one-dimensional analysis of variance (ANOVA).

\section{Results}

\subsection{Meteorological Conditions during the Study Years}

The weather conditions in 2016-2018 varied (Figure 3). In all study years, the mean annual air temperature was higher than the average value in 1980-2015. During the experiment, 2018 was the coldest year (mean annual air temperature: $8.0^{\circ} \mathrm{C}$; mean temperature in the March-October growing season: $12.3^{\circ} \mathrm{C}$ ). The highest air temperatures, both the annual mean and the mean for the growing season, were noted in $2016\left(9.5^{\circ} \mathrm{C}\right.$ and $13.1^{\circ} \mathrm{C}$, respectively). The same year (2016) was characterised by the highest annual precipitation rates and the highest value of this parameter for the growing season $(16.8 \%$ and $19.8 \%$ higher rates than the multiannual precipitation sums, respectively). In turn, precipitation deficits were recorded in 2017 (6.3\% and 32.9\% lower rates than the multiyear mean, respectively). 


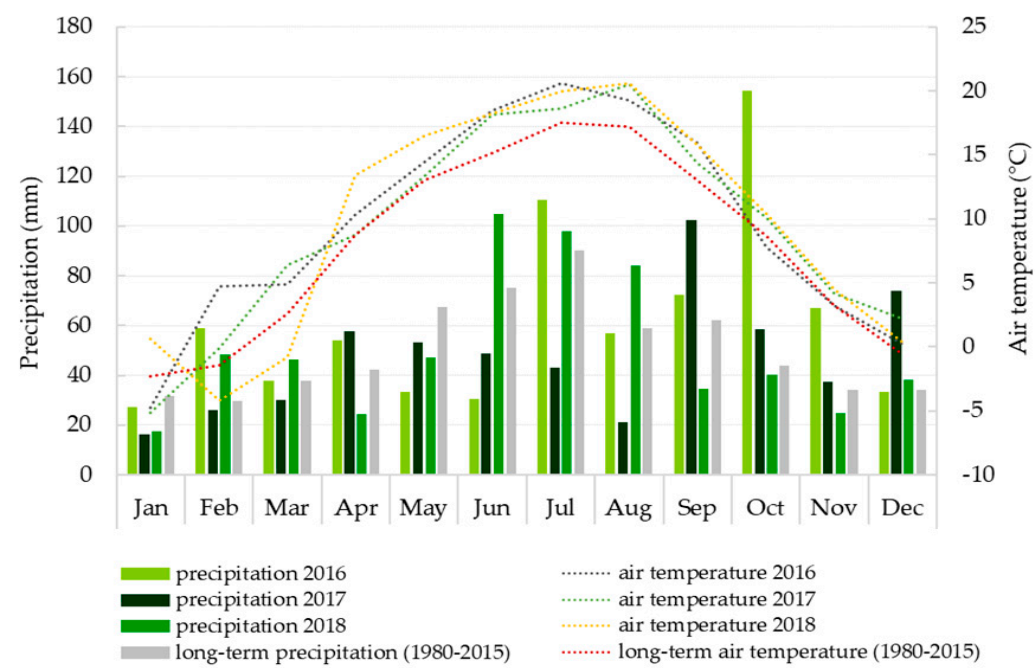

Figure 3. Meteorological conditions during the study period (2016-2018).

\subsection{Selected Properties of the Investigated Soil in the Different Types of Tillage Systems}

The soils collected from the selected plots subjected to the conventional tillage (C_Ts) contained on average $6.2 \%$ of sand, $83.5 \%$ of silt, and $10.3 \%$ of clay. In the C_TS variant, most soils had a granulometric composition corresponding to silt ( $\mathrm{Si}$ ), while one soil was identified as silty loam (SiL). The average content of sand, silt, and clay in the soils from the simplified tillage system (S_Ts) was 6.0,79.2, and 14.8\%, respectively. In terms of their granulometric composition, all soils in this group were classified as silty loam (SiL). In the O_Fs soils, the mean content of sand, silt, and clay was $1.5,86.3$, and $12.2 \%$, respectively. All soils in this group were classified as silt (Si) (Table 2).

Table 2. Basic properties of arable soils in the different cultivation systems.

\begin{tabular}{|c|c|c|c|c|c|c|}
\hline \multirow[b]{2}{*}{ Object } & \multicolumn{4}{|c|}{ Granulometric Composition of Soil (\%) } & \multirow[b]{2}{*}{$\mathrm{pH}_{\mathrm{H}_{2} \mathrm{O}}$} & \multirow[b]{2}{*}{$\mathrm{EC}(\mu \mathrm{S})$} \\
\hline & $\begin{array}{c}\text { Sand } \\
(2.0-0.05 \mathrm{~mm})\end{array}$ & $\begin{array}{c}\text { Silt } \\
(0.05-0.002 \mathrm{~mm})\end{array}$ & $\begin{array}{c}\text { Clay } \\
(<0.002 \mathrm{~mm})\end{array}$ & $\begin{array}{c}\text { Granulometric } \\
\text { Fraction (USDA) }\end{array}$ & & \\
\hline $1 \mathrm{C}_{-} \mathrm{Ts}$ & 1 & 87 & 12 & $\mathrm{Si}$ & $7.58^{b c} \pm 0.03$ & $282^{b-d} \pm 34$ \\
\hline $2 C_{-}$Ts & 1 & 89 & 10 & $\mathrm{Si}$ & $7.20^{a-c} \pm 0.56$ & $174^{\mathrm{ab}} \pm 62$ \\
\hline $3 C_{-}$Ts & 1 & 91 & 8 & $\mathrm{Si}$ & $7.58^{b c} \pm 0.09$ & $354^{\mathrm{d}} \pm 40$ \\
\hline $4 \mathrm{C}_{-} \mathrm{Ts}$ & 1 & 90 & 9 & $\mathrm{Si}$ & $7.7^{c} \pm 0.08$ & $248^{\mathrm{a}-\mathrm{d}} \pm 37$ \\
\hline $5 \mathrm{C}_{-} \mathrm{Ts}$ & 31 & 63 & 6 & SiL & $7.02^{\mathrm{a}-\mathrm{c}} \pm 0.74$ & $256^{\mathrm{a}-\mathrm{d}} \pm 67$ \\
\hline $6 C_{-} \mathrm{Ts}$ & 2 & 81 & 17 & $\mathrm{Si}$ & $7.24^{\mathrm{a}-\mathrm{c}} \pm 0.58$ & $233^{a-d} \pm 63$ \\
\hline Mean \pm SE C_Ts & 6.2 & 83.5 & 10.3 & - & $7.39^{a} \pm 0.11$ & $257.8^{a} \pm 16.8$ \\
\hline $1 \mathrm{~S} \_\mathrm{Ts}$ & 2 & 81 & 17 & SiL & $6.79^{a-c} \pm 0.45$ & $210^{a-c} \pm 33$ \\
\hline $2 S$ S_Ts & 1 & 83 & 16 & $\mathrm{SiL}$ & $6.89^{a b} \pm 0.30$ & $260^{\mathrm{ab}} \pm 46$ \\
\hline $3 \mathrm{~S} \_\mathrm{Ts}$ & 1 & 82 & 17 & SiL & $6.71^{\mathrm{ab}} \pm 0.22$ & $327^{\mathrm{ab}} \pm 59$ \\
\hline $4 \mathrm{~S} \_\mathrm{Ts}$ & 1 & 80 & 19 & SiL & $6.53^{a} \pm 0.09$ & $169^{\mathrm{ab}} \pm 42$ \\
\hline $5 \mathrm{~S} \_\mathrm{Ts}$ & 4 & 83 & 13 & SiL & $6.49^{a-c} \pm 0.61$ & $179^{\mathrm{a}-\mathrm{d}} \pm 23$ \\
\hline $6 \mathrm{~S} \_\mathrm{Ts}$ & 27 & 66 & 7 & SiL & $6.26^{\mathrm{ab}} \pm 0.35$ & $167^{a} \pm 29$ \\
\hline Mean \pm SE S_Ts & 6.0 & 79.2 & 14.8 & - & $6.56^{c} \pm 0.09$ & $218.8^{\mathrm{ab}} \pm 16.2$ \\
\hline 10_Ts & 1 & 89 & 10 & $\mathrm{Si}$ & $6.86^{\mathrm{a}-\mathrm{c}} \pm 0.08$ & $254^{\mathrm{d}} \pm 72$ \\
\hline 2 O_Ts & 1 & 85 & 14 & $\mathrm{Si}$ & $6.58^{a-c} \pm 0.27$ & $143^{\mathrm{ab}} \pm 29$ \\
\hline $3 \mathrm{O} \_\mathrm{Ts}$ & 1 & 86 & 13 & $\mathrm{Si}$ & $7.31^{\mathrm{a}-\mathrm{c}} \pm 0.13$ & $365^{a} \pm 44$ \\
\hline 4 O_Ts & 1 & 89 & 10 & $\mathrm{Si}$ & $7.22^{\mathrm{a}-\mathrm{c}} \pm 0.24$ & $152^{\mathrm{a}} \pm 28$ \\
\hline 5O_Ts & 2 & 84 & 14 & $\mathrm{Si}$ & $6.92^{\mathrm{a}-\mathrm{c}} \pm 0.35$ & $133 \pm 16$ \\
\hline $6 \mathrm{O}_{-} \mathrm{T}$ s & 3 & 85 & 12 & $\mathrm{Si}$ & $7.00^{a-c} \pm 0.09$ & $126 \pm 28$ \\
\hline Mean \pm SE O_Fs & 1.5 & 86.3 & 12.2 & - & $6.98^{b} \pm 0.07$ & $195.5^{c} \pm 22.6$ \\
\hline
\end{tabular}


In the groups of soils collected in the different tillage systems, the $\mathrm{pH}$ values determined in water were similar. The $\mathrm{pH}$ of the $\mathrm{C}_{-} \mathrm{Ts}$ soils ranged from 7.02 to 7.71 (mean 7.39) and did not differ significantly between the plots in this group. Moreover, the soils from the conventional tillage system were characterised by significantly higher $\mathrm{pH}$ values than the soils from the other objects. The $\mathrm{pH}$ value indicated the reaction of the soils. All the C_Ts and O_Fs soils were neutral, whereas the S_Ts soils were slightly acidic to neutral (Table 2).

The mean electrolytic conductivity (EC) values were in the range of 195.5-257.8 $\mu \mathrm{S}$, with the highest values in the C_Ts group of soils and the lowest values in the O_Fs soils (Table 2).

\subsection{Soil Organic Carbon (SOC), Total Nitrogen (Nt), and C:N Ratio in Soils from the Different Tillage Systems}

The tillage system had a significant effect on the mean content of soil organic carbon (SOC) (Figure 3). In all study years, the highest mean SOC content was determined in the S_Ts soils, and the lowest level was exhibited by the O_Fs group. The mean SOC content in the S_Ts soils was in the range of $25.1-27.9 \mathrm{~g} \mathrm{~kg}^{-1}$, with the highest level in the 1st year of the study. The SOC values determined for each plot in the S_Ts group were similar in the 1 st and 2 nd years of the experiment. In turn, they were characterised by high variability in the 3rd year, as evidenced by the large differences between the minimum and maximum value (Figure 4). The lowest mean SOC content was recorded in the O_Fs soils, compared to the other variants. The values determined for these soils showed low variability between the compared plots. Moreover, a clear trend towards a decline in the SOC content was observed in these soils during the consecutive years in comparison with the 1st year of the study. The initial SOC content in these soils was $13.3 \mathrm{~g} \mathrm{~kg}^{-1}$ in 2016 and $10.1 \mathrm{~g} \mathrm{~kg}^{-1}$ in 2018.
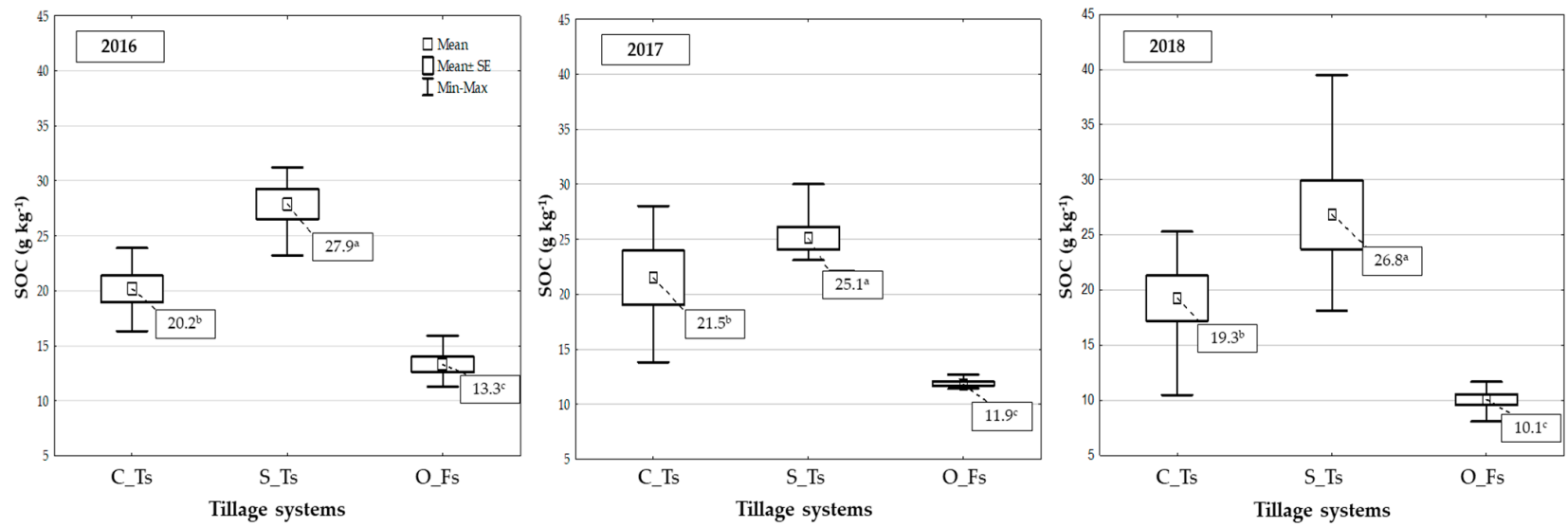

Figure 4. Content of SOC in soils from the different tillage systems during the study years (2016-2018). Mean values $(n=18) \pm$ standard error. Identical superscripts denote no significant $(p>0.05)$ differences between soils from the different tillage systems according to the post-hoc Tukey HDS test.

Similar relationships were also observed for the content of $\mathrm{Nt}$. As in the case of SOC, the highest mean Nt content was recorded in the S_Ts soils, and this value was significantly higher than in the other soil groups. The mean content of $\mathrm{Nt}$ in the soils of this group in the 1st and 2nd years of the study was the same, and the results obtained for the analysed plots exhibited low variability (Figure 5). As in the case of SOC, high variability of the results obtained for each plot was observed in the last year of the study, which is evidenced by the large differences between the minimum and maximum value of Nt (Figure 5). Relatively stable mean $\mathrm{Nt}$ content throughout the study was also determined in the C_Ts soils. As in the case of SOC, the lowest mean Nt content was determined in the O_Fs soils. It ranged from $1.25 \mathrm{~g} \mathrm{~kg}^{-1}$ to $0.97 \mathrm{~g} \mathrm{~kg}^{-1}$, showing a clear downward trend with time compared to the 1st study year (Figure 5). 

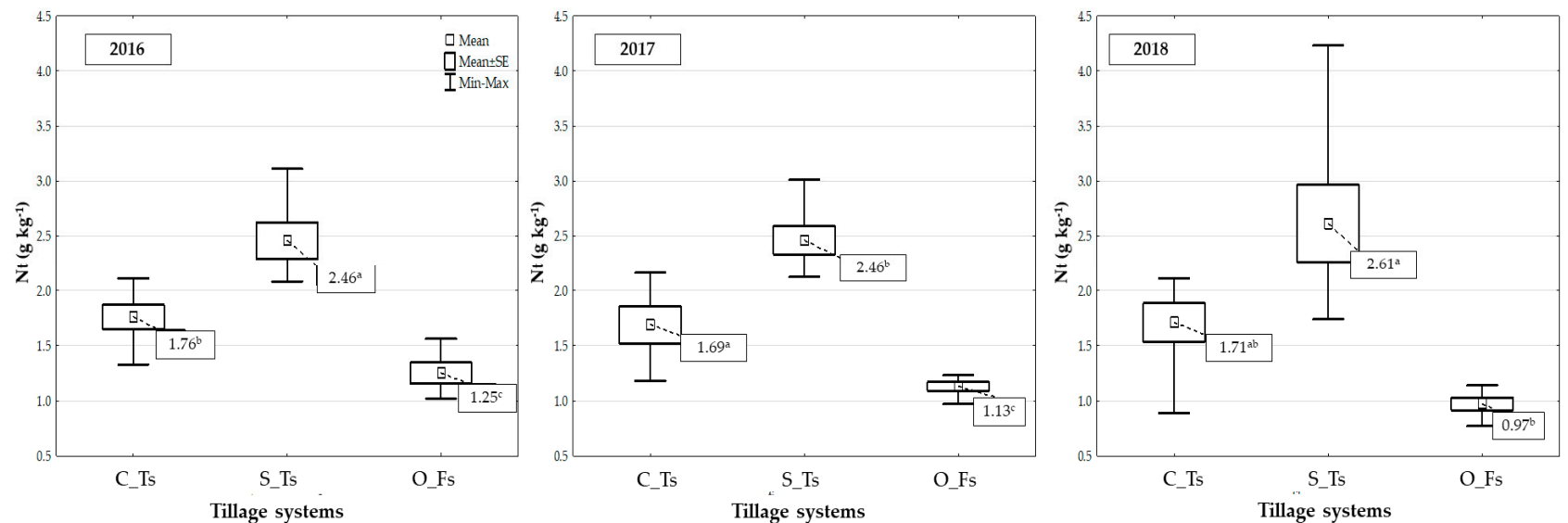

Figure 5. Content of total nitrogen $(\mathrm{Nt})$ in soils from the different tillage systems during the study years (2016-2018). Mean values $(n=18) \pm$ standard error. Identical superscripts denote no significant $(p>0.05)$ differences between soils from the different tillage systems according to the post-hoc Tukey HDS test.

The C:N ratio is directly associated with the SOC and Nt contents. Relatively low C:N ratios were noted in the analysed soils. These relationships were observed throughout the study. There was no significant effect of the cultivation systems on the mean value of the $\mathrm{C}: \mathrm{N}$ ratio. In turn, considerable fluctuations of this parameter were observed in the soils from the individual plots, especially in the C_Ts soils (Figure 6).
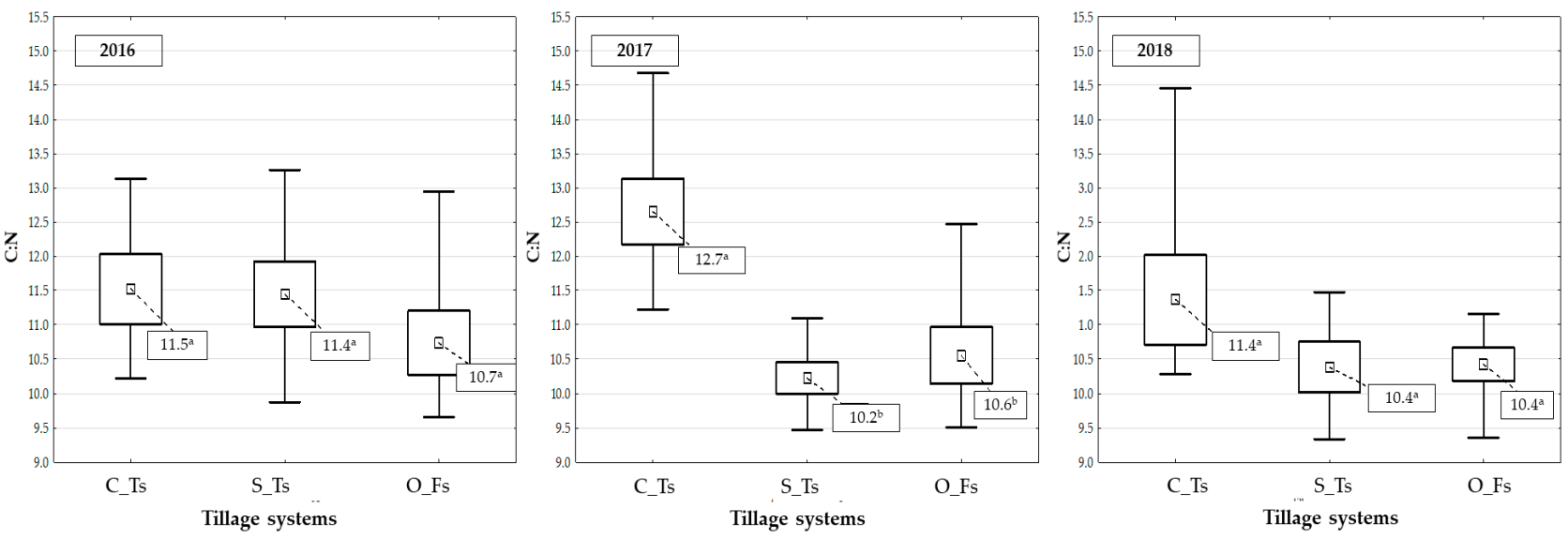

Figure 6. C:N ratio in soils from the different tillage systems during the study years (2016-2018). Mean values $(n=18) \pm$ standard error. Identical superscripts denote no significant $(p>0.05)$ differences between soils from the different tillage systems according to the post-hoc Tukey HDS test.

\subsection{Fractional Composition of Organic Matter}

The process of organic matter fractionation consisted of the determination and calculation of the following values: carbon content after extraction in the mixture of $1 \mathrm{M} \mathrm{NaOH}$ and $\mathrm{Na}_{4} \mathrm{P}_{5} \mathrm{O}_{7}\left(\mathrm{C}_{\text {ext }}\right)$, humic acid carbon $\left(\mathrm{C}_{\mathrm{HAs}}\right)$, fulvic acid carbon $\left(\mathrm{C}_{\mathrm{FAs}}\right)$, and humin carbon $\left(\mathrm{C}_{\mathrm{H}}\right)$.

The mean $C_{\text {ext }}$ values ranged from 5.82 to $16.49 \mathrm{~g} \mathrm{~kg}^{-1}$ (Table 3). The parameter depended on the tillage system: it had the highest values in the S_Ts soils and the lowest value in the $\mathrm{O}_{-}$Fs system. Moreover, the determined $\mathrm{C}_{\text {ext }}$ values exhibited large variation between the individual experimental plots, as evidenced by the large differences between the minimum and maximum values. Similar relationships were also found in the case of the other organic matter fractions (Table 3). The $\mathrm{C}_{\mathrm{HAs}} / \mathrm{C}_{\mathrm{FAs}}$ ratio is directly related to the content of humic and fulvic acids. The values of the calculated $\mathrm{C}_{\mathrm{HAs}} / \mathrm{C}_{\mathrm{Fas}}$ ratio ranged from 0.91 to 1.21 and did not differ significantly between the different experimental 
variants (Table 3). In addition to the $\mathrm{C}_{\mathrm{HAs}} / \mathrm{C}_{\mathrm{FAs}}$ parameter, the quality of soil humus is determined based on the percentage share of its individual fractions in the SOC pool (Figure 7). Regardless of the cultivation systems and the study year, the humin $\left(\mathrm{C}_{\mathrm{H}}\right)$ fraction represented the highest proportion in the SOC pool. In the individual years of the study, $\mathrm{C}_{\mathrm{H}}$ accounted for $44.5-55.0 \%, 41.4-56.6 \%$, and $45.9-55.3 \%$ of the SOC pool in the C_Ts, S_Ts, and O_Fs soils, respectively (Figure 7). The highest share of $\mathrm{C}_{\mathrm{H}}$ in the SOC pool in all the experimental variants was recorded in the 2nd year of the study. In the last year, there was a clear decrease in the proportion of the $\mathrm{C}_{\mathrm{H}}$ fraction accompanied by an increase in the proportion of the $\mathrm{C}_{\mathrm{FAs}}$ fraction in the SOC pool in all the experimental variants (Figure 7).

Table 3. Soil organic matter fractions in soils from the different tillage systems (mean for the study years 2016-2018).

\begin{tabular}{|c|c|c|c|c|c|c|}
\hline \multirow{2}{*}{$\begin{array}{l}\text { Tillage } \\
\text { System }\end{array}$} & \multirow{2}{*}{ Parameters } & \multicolumn{5}{|c|}{ Soil Organic Matter Fraction $\left(\mathrm{g} \mathrm{kg}^{-1}\right)$} \\
\hline & & $\mathrm{C}_{\text {ext }}$ & $\mathrm{C}_{\text {HAs }}$ & $\mathrm{C}_{\mathrm{FAs}}$ & $\mathrm{C}_{\mathrm{HAs}} / \mathrm{C}_{\mathrm{FAs}}$ & $\mathrm{C}_{\mathrm{H}}$ \\
\hline \multirow{4}{*}{ C_Ts } & Mean & $8.89^{b}$ & $4.16^{\mathrm{ab}}$ & $4.88^{b}$ & $0.91^{\mathrm{a}}$ & $11.04^{b}$ \\
\hline & Min & 5.30 & 1.44 & 3.03 & 0.37 & 5.20 \\
\hline & Max & 14.13 & 8.66 & 9.71 & 2.08 & 19.00 \\
\hline & SE & 0.59 & 0.39 & 0.37 & 0.11 & 0.92 \\
\hline \multirow{4}{*}{ S_Ts } & Mean & $16.49^{a}$ & $5.41^{\mathrm{a}}$ & $6.49^{a}$ & $0.91^{\mathrm{a}}$ & $14.68^{a}$ \\
\hline & Min & 7.37 & 2.93 & 3.62 & 0.37 & 5.00 \\
\hline & Max & 23.77 & 11.12 & 12.65 & 2.08 & 22.60 \\
\hline & SE & 0.83 & 0.48 & 0.52 & 0.11 & 0.89 \\
\hline \multirow{4}{*}{ O_Fs } & Mean & $5.82^{\mathrm{c}}$ & $2.99^{\mathrm{C}}$ & $2.83^{c}$ & $1.22^{\mathrm{a}}$ & $6.20^{c}$ \\
\hline & Min & 4.38 & 1.19 & 1.42 & 0.37 & 3.00 \\
\hline & Max & 8.32 & 4.37 & 4.93 & 2.51 & 11.10 \\
\hline & SE & 0.27 & 0.21 & 0.24 & 0.15 & 0.39 \\
\hline
\end{tabular}

Explanation: $\mathrm{C}_{\mathrm{ext}}$-carbon extracted in $1 \mathrm{M} \mathrm{NaOH}$ and $\mathrm{Na}_{4} \mathrm{P}_{5} \mathrm{O}_{7}$ mixture; $\mathrm{C}_{\mathrm{Has}}$ - humic acid carbon; $\mathrm{C}_{\mathrm{FAs}}$-fulvic acid carbon; $\mathrm{C}_{\mathrm{H}}$-humin carbon. Mean values $(n=18) \pm$ standard error. Identical superscripts denote no significant $(p>0.05)$ differences between soils from the different tillage systems (in the rows) according to the post-hoc Tukey HDS test.

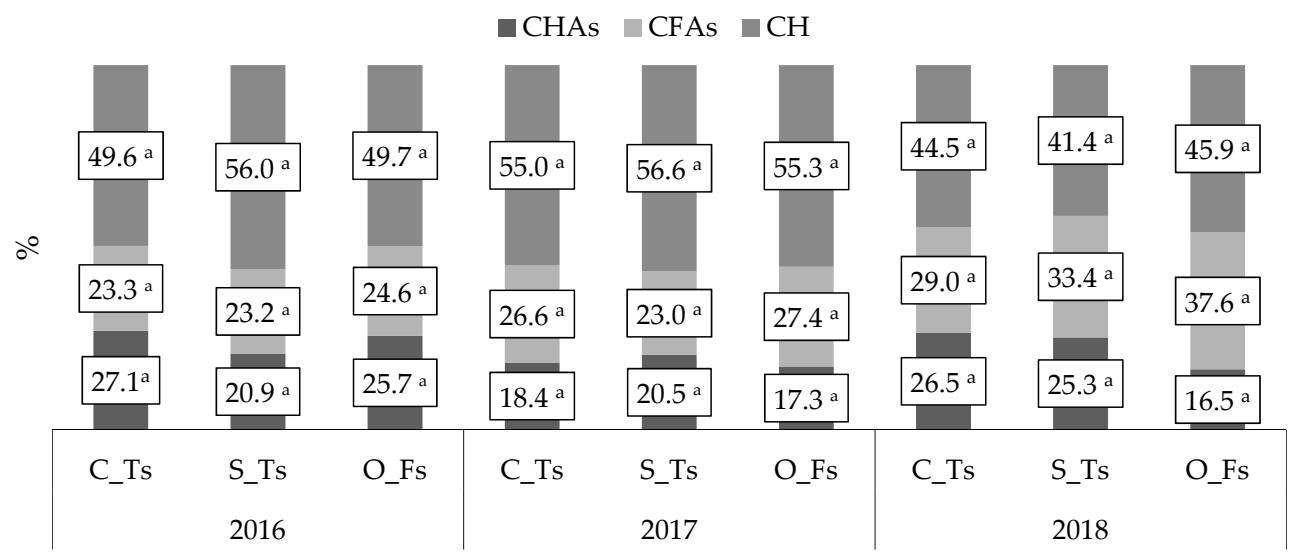

Figure 7. Share of soil organic matter fractions in the SOC pool in the different tillage systems. Mean values $(n=6)$. Identical superscripts denote no significant $(p>0.05)$ differences between soils from the different tillage systems in the particular year according to the post-hoc Tukey HDS test.

\subsection{Soil Enzymatic Activity}

In the present study, the dehydrogenase (DH) activity differed significantly depending on the cultivation systems and the year of the study (Figure 8). The highest DH activity was recorded in the O_Fs soils throughout the study. The mean DH value in this group of 
soils was very stable and ranged from 6.01 to $6.11 \mu \mathrm{mol} \mathrm{TPF} \cdot \mathrm{kg}^{-1} \cdot \mathrm{h}^{-1}$. Similarly, the mean DH activity in the S_Ts soils was high and ranged from 4.96 to $5.32 \mu \mathrm{mol} \mathrm{TPF} \cdot \mathrm{kg}^{-1} \cdot \mathrm{h}^{-1}$ throughout the study. In comparison with the O_Fs and S_Ts systems, the mean DH activity in the C_Ts soils was significantly lower and ranged from 3.59 to $4.85 \mu \mathrm{mol}$ TPF $\cdot \mathrm{kg}^{-1} \cdot \mathrm{h}^{-1}$ during the study years. The comparison of the S_Ts and O_Fs soils revealed no significant differences in the DH activity in the 1st and 3rd study years. In turn, the mean DH activity in the 2nd year of the experiment was significantly higher in the O_Fs soils (Figure 8).
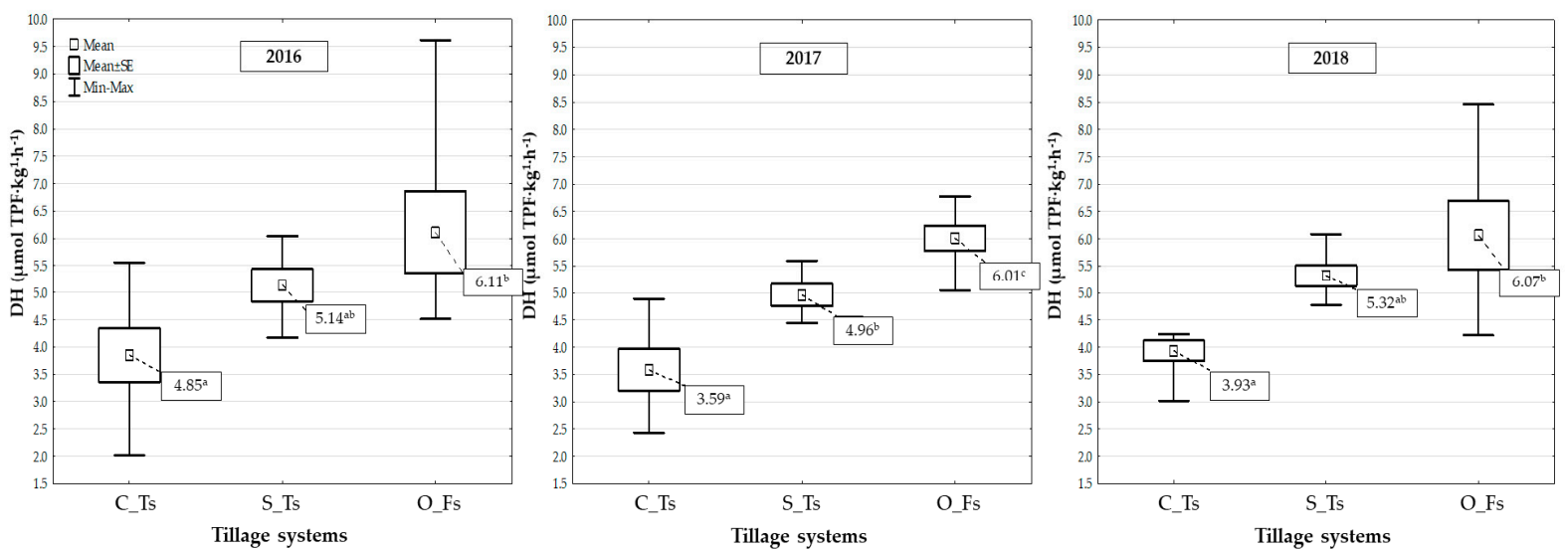

Figure 8. Dehydrogenase activity (DH) in soils from the different tillage systems during the study years (2016-2018). Mean values $(n=18) \pm$ standard error. Identical superscripts denote no significant $(p>0.05)$ differences between soils from the different tillage systems according to the post-hoc Tukey HDS test.

The highest catalase (CAT) activity was determined in the O_Fs soils. In the study years, it ranged from 0.156 (2nd year) to 0.177 (1st year) $\mathrm{mg} \mathrm{H}_{2} \mathrm{O}_{2} \cdot \mathrm{g}^{-1} \mathrm{~d} \cdot \mathrm{w} \cdot \mathrm{min}^{-1}$. Despite the higher values of the activity of this enzyme in the O_Ts soils, there were no significant differences in comparison with the other experimental _C__Ts and S_Ts (Figure 8). It was also observed that, mainly in the 1st and 3rd years of the experiment, the CAT activity in the O_Fs soils exhibited high variability, as evidenced by the large differences between the maximum and minimum values (Figure 9).
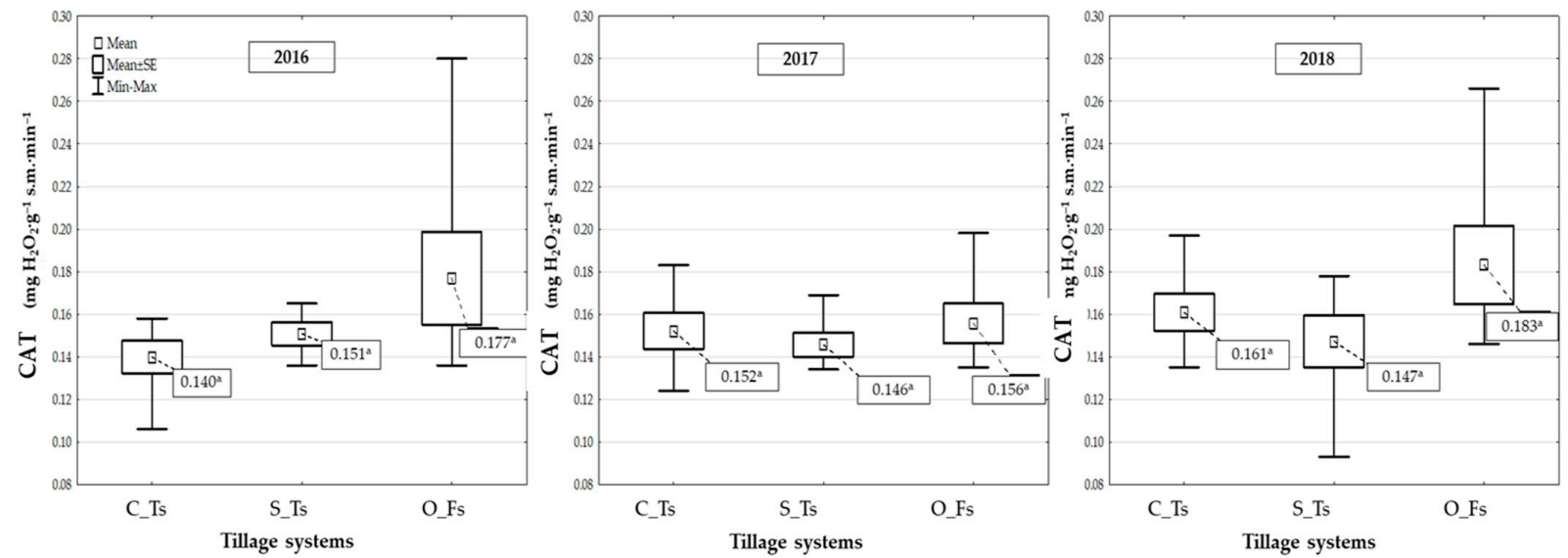

Figure 9. Catalase activity (CAT) in soils from the different tillage systems during the study years (2016-2018). Mean values $(n=18) \pm$ standard error. Identical superscripts denote no significant $(p>0.05)$ differences between soils from the different tillage systems according to the post-hoc Tukey HDS test.

\section{Discussion}

The organic matter content in soils and especially its most important component, i.e., soil humus, undergoes continuous quantitative and qualitative changes; therefore, it is not 
a constant value [37]. Agrotechnical treatments exert an impact on the accumulation of soil organic matter. They determine e.g., the rate of the decomposition of post-harvest residues or natural fertilisers delivered to the soil, which is reflected in the quality and chemical composition of soil humus [38]. The negative impact of conventional tillage on soil humus content, i.e., an increase in its mineralisation rate, is widely documented in the literature. Simplified tillage and organic farming systems contribute to an increase in the soil humus level $[1,2,5,12,14]$. The present study has confirmed the beneficial effect of S_Ts on the SOC content. Regardless of the applied fertilisation (mineral or organic) and the crops cultivated, the highest soil organic carbon and total nitrogen content were on soils under simplified tillage systems compare to soils under conventional tillage and organic farming. The mean concentration of organic carbon in soil surface layers under S_Ts was more than 30\% higher than in soils under C_Ts and more than $120 \%$ higher than in soils under O_Fs (Figure 3 ). It indicates that any simplifications in the tillage systems and reduced interference with soil surface layers most exposed to the impact of agrotechnical treatments enhance organic matter accumulation.

In the simplified tillage system, plant residues are left on the soil every year, and their decomposition and transformation increase the amount of organic carbon in the topsoil [8]. Moreover, the reduced cultivation intensity slows down the rate of organic matter decomposition, which undoubtedly contributes to an increase in its content in the soil [7]. It is commonly believed that conventional (plough) tillage, in contrast to simplified tillage, has an especially negative effect on the content of organic matter through the strong and systematic interference with the soil system and may reduce the content of organic matter in the soil by up to 50\% within 20 years [39,40]. As mentioned above, in soils under organic farming systems, the lowest organic carbon content was found. As in the conventional system, plowing was one of the cultivation treatments in these soils. Regardless of regular natural fertilisation applied on these soils, interference with the surface layers of these soils due to plowing caused a higher rate of transformation and mineralization, which was probably affected on organic carbon losses.

It is well known that the type of crop plants and crop rotation are the most important factors increasing the organic carbon content in soil $[19,40]$. This is associated with, for example, the amount of post-harvest residues and requirements for the preparation of the land for crop cultivation [23]. In general, the levels of organic carbon and total nitrogen are higher in soils where crop rotation is applied than in soils where plants are grown in monoculture [24,40]. Fabaceae plants and their mixtures with grasses as well as pulses have high organic matter reproduction potential. In turn, root crops and maize contribute to depletion of soil organic matter [40]. They produce small amounts of crop residues, and they are planted in wide rows. Additionally, the late achievement of plant cover density intensifies the processes of mineralisation of organic matter, which does not support its accumulation in soils. Cereals and oilseed plants exert a low negative or neutral impact. Winter wheat and oilseed rape with some amounts of maize and soybean were most often cultivated in the analysed conventional tillage soils (C_Ts) (Figure 2). Similarly, cereals, oilseed crops, and occasionally sugar beets and maize were most often grown in the S_Ts soils. The lowest levels of organic carbon in the organic farming (O_Fs) soils may have been caused by the farming treatments (ploughing) and the crop structure, as winter wheat, oilseed rape, and potatoes were most often grown in these soils. The amount of cereal residue is approximately 3 -fold higher than that of root crop residues. Moreover, the yield of arable crops in soils in the organic farming system is approximately $19 \%$ lower than in the conventional tillage system. This in turn is associated with lower amounts of plant residues, which are a source of soil organic matter [17]. It should be emphasised, however, that in addition to their amount, the chemical composition of crop residues is important, as it determines their degradation and transformation in soils. Post-harvest residues of oilseed rape and wheat are characterised by high $C: N$ and $C: P$ ratios and high content of lignin, which is difficult to degrade in the soil [13]. Depending on the species or cultivar, crops can influence the biochemical and microbiological activity of the soil 
in a variety of ways through the effect of their root exudates. Thus, they can exert an indirect effect on the processes of transformation and accumulation of organic matter in the soil [25]. In soils with high biological activity, post-harvest crop residues are decomposed rapidly. Depending on the cultivation system and soil biological activity, the quantitative and qualitative transformations may have two opposite directions, i.e., mineralisation or humification $[24,37,41]$.

The properties of soil humus depend on many factors and, simultaneously, they are specific to the types of soil. Humic acids are the main components of soil humus determining its properties and role in the natural environment. It is widely known that the content of humic acids in arable soils is primarily determined by the fertilisation type $[13,42]$.

The tillage system significantly differentiated the content of the organic carbon fractions. The highest mean content of $\mathrm{C}_{\mathrm{HAs}}, \mathrm{C}_{\mathrm{FAs}}$, and $\mathrm{C}_{\mathrm{H}}$ was detected in the $\mathrm{S}_{-} \mathrm{Ts}$ soils, and the lowest value was reported for the O_Ts soils (Table 3). As shown in Figure 6, the tillage system did not exert a significant effect on the percentage of the organic carbon fractions. In all the experimental variants, the $\mathrm{C}_{\mathrm{H}}$ fraction accounted for the highest percentage in the total organic carbon content (SOC) throughout the study years. The contribution of $\mathrm{C}_{\mathrm{HAs}}$ and $\mathrm{C}_{\mathrm{Fas}}$ to the $\mathrm{SOC}$ pool exhibited slight fluctuations depending on the cultivation systems and the study year (Table 3). Humins are the most resistant fraction to microbiological decomposition and leaching; hence, their higher levels in soils indicate relative persistence and stability of soil humus. It can be assumed that the $\mathrm{C}_{\mathrm{H}}$ content determined in the analysed soil groups indicate relatively stable and unchangeable resources of this element. The $\mathrm{C}_{\mathrm{HAs}}: \mathrm{C}_{\mathrm{FAs}}$ ratio is directly associated with the $\mathrm{C}_{\mathrm{HAs}}$ and $\mathrm{C}_{\mathrm{FAs}}$ contents. Higher values of this ratio are typical of more fertile soils with a high degree of organic matter humification. The values of the $\mathrm{C}_{\mathrm{HAs}} / \mathrm{C}_{\mathrm{Fas}}$ ratio did not differ significantly between the experimental variants, which may indicate that none of the cultivation systems used disturbed the soil system equilibrium in the specific habitat conditions [13].

Nitrogen is a well-known essential element required for the proper development of crops. In soils, it usually occurs in insufficient amounts to meet the nutritional needs of plants; therefore, it is supplied with mineral or organic fertilisers, often in amounts substantially exceeding the recommended doses. The mean content of $\mathrm{Nt}$ in the analysed soil levels differed significantly between the experimental variants (Figure 5). As in the case of the SOC content, the lowest Nt content was determined in the O_Fs soils. The mean $\mathrm{Nt}$ content in these soils not only had the lowest value compared to the other experimental plots but also clearly declined over time. The differences in the Nt levels in the soils of the experimental variants resulted from several factors, e.g., the organic matter content, the crop type, or the applied mineral and organic fertilisation. In the analysed cultivation systems, the doses of $\mathrm{N}$ per pure component supplied to the arable crops varied largely irrespective of the type of fertilisation used (mineral or organic) (Table 1). The highest level of $\mathrm{N}$ fertilisation per pure component was applied to the most commonly cultivated plants (winter wheat and winter oilseed rape) in the S_Ts soils, compared to the other cultivation systems. The soils in the O_Fs group were fertilised only with organic fertilisers (manure). Fertilisation with manure enhances the accumulation of organic matter and plant nutrients and improves the soil retention capacity through improvement of the soil structure. On the other hand, inorganic fertilizers indirectly influence SOC concentration by increasing crop yields and thereby increasing the return of crop residues to the soil. As proven in the present study, fertilisation alone does not produce an increase in the organic matter and $\mathrm{Nt}$ contents in soils, but some simplification of the cultivation system is required. Ploughing was the main tillage treatment applied in the O_Fs soils. As frequently emphasised before, the ploughing tillage system increases soil oxygenation, thereby contributing to faster mineralisation of organic matter and leaching of simple inorganic compounds generated in this process into deeper layers of the soil profile and then into groundwater [27-29]. The O_Fs soils were also characterised by the highest biological activity, which may have accelerated the mineralisation of exogenous organic matter supplied with the fertilisers. 
As shown by various investigations, the content of some organic matter fractions, such as humic acids, is closely related to the content of total nitrogen in the soil, as this element is one of the main components of these compounds [42,43]. This relationship was also confirmed in the present study, i.e., the highest mean $\mathrm{C}_{\mathrm{HAs}}$ content was determined in the S_Ts soils, which exhibited the highest Nt level as well, compared to the other objects (Table 3). In turn, the lowest $\mathrm{Nt}$ and $\mathrm{C}_{\text {Has }}$ levels were recorded in the O_Fs soils, which may have been associated with the amount of nutrients supplied with the fertilisers. In the case of the O_Fs soils, the natural fertilisation (manure) provided the lowest amounts of pure $\mathrm{N}$, in comparison with the other experimental objects, which was undoubtedly correlated with the content of this element in the soil.

The C:N ratio is directly associated with the soil SOC and Nt contents. It is a very important indicator determining the activity of soil microorganisms and thus influencing the $\mathrm{C}$ and $\mathrm{N}$ cycle and the decomposition of post-harvest crop residues [44]. Relatively lower values of the $C: N$ ratio are crucial for the utilisation of $C$ and $\mathrm{N}$ by soil microorganisms, which has an impact on the release of larger amounts of nutrients into the soil and thus on soil fertility. Therefore, the C:N ratio provides important information about the $\mathrm{C}$ and $\mathrm{N}$ cycle in soils [45]. In general, the impact of cultivation systems on the C:N ratio is poorly known [46]. The present study did not confirm unequivocally the effect of different tillage systems on the value of this parameter. The mean values of the C:N ratio in the analysed cultivation systems exhibited relatively small fluctuations in the study years (Figure 6). Noteworthy, the values of this parameter may also depend on meteorological conditions, i.e., the higher degree of nitrogen leaching from the soil induced by intense rainfall results in higher values of the $C: N$ ratio. The air temperature has a significant impact on the value of this parameter as well. The higher the temperature, the lower the $C: \mathrm{N}$ ratio values.

Soil enzymatic activity, which varies depending on the farming systems and fertilisation, is a sensitive indicator of environmental changes $[4,25,31,32,47,48]$. In the group of soil enzymes, the activity of dehydrogenase is highly important, as this intracellular enzyme provides information about the biological activity of soil microflora [25]. The dehydrogenase activity depends on various factors in the soil, e.g., moisture, redox potential, and organic matter content [48].

In the present study, the highest values of the activity of enzymes from the oxidoreductase group were observed in the O_Fs soils, and this trend persisted throughout the study. This confirms the conclusions reported in the literature on the increased biochemical activity and biodiversity of soils in organic farming systems versus conventional tillage [16,21,32]. This is mainly related to the discontinuation of the application of large amounts of mineral fertilisers and chemical plant protection products, as is the case in intensive agriculture. Soil enzymatic activity depends on different factors associated with soil properties (e.g., $\mathrm{pH}$, SOC, nutrient content, texture) and environmental factors (e.g., precipitation, temperature, sunshine). As reported by Acosta-Martínez and Waldrip (2014), enzyme activities are higher in clay and loamy soils than in sandy soils [49]. Additionally, enzyme activities have also been used as an early indicator of changes in soil quality because they are more sensitive to changes in land use or management practices than other soil properties [50]. It is well known that any simplifications of cultivation and reduction of interference with the soil surface layers increase the enzyme activity of soils [3]. These observations were also confirmed in the present analyses of the activity of the selected soil enzymes, as the highest enzyme activity was determined in the O_Fs soils and in the S_Ts soils. This also proves that the reduction of mineral fertilisation on the one hand and the lower interference with the topsoil on the other hand contribute to maintenance of soil fertility and ensure achievement of stable crops.

\section{Conclusions}

The research assessed the influence of different tillage systems (conventional, simplified, and organic farming) on selected soil properties (organic carbon content, total nitrogen content, organic matter fractional composition, and enzymatic activity). The effect of tillage 
systems on selected soil properties was assessed on arable soils of private farms. The conclusions of the conducted research are as follows:

1. Regardless of the applied fertilisation (mineral or organic) and the crops cultivated, the highest soil organic carbon and total nitrogen content were on soils under simplified tillage systems. The mean concentration of organic carbon in soil surface layers under simplified tillage systems was more than $30 \%$ higher than in soils under conventional tillage systems and more than $120 \%$ higher than in soils under organic farming. It indicates that any simplifications in the tillage systems and reduced interference with soil surface layers most exposed to the impact of agrotechnical treatments enhance organic matter accumulation.

2. The lowest soil organic carbon and total nitrogen concentration were found in soils under organic farming. This indicates that not only organic fertilisation but also any simplification of tillage systems are important considerations to maintaining organic carbon resources.

3. Compared to other tillage systems, the soils of the organic farming system were characterised by the highest enzymatic activity. Limitation of the chemisation of agriculture through organic farming contributes to an increase in the biochemical activity of soils. Mean dehydrogenase activity on soil surface layers under organic farming systems during the study years was higher than simplified tillage systems and conventional tillage systems by 18 and $60 \%$, respectively. In the long term, organic farming systems can help maintain natural fertility and productivity of soils, thus ensuring the stability of crops and food security for future generations.

Author Contributions: Conceptualisation, M.S.; methodology, M.S., E.S.-K. and R.P.; formal analysis, E.S.-K., A.I. and J.S.-T.; investigation, M.S., R.P. and A.I.; writing-original draft preparation, M.S. and E.S.-K.; visualisation, M.S. and A.I.; writing - review and editing, M.S. and E.S.-K. All authors have read and agreed to the published version of the manuscript.

Funding: The present research and Open Access fees were partially funded with a subsidy to maintain the Department of Soil Science, Environmental Chemistry and Hydrology research potential of the University of Rzeszów for 2020-2021.

Data Availability Statement: The entire set of raw data presented in this study is available on request from the corresponding author.

Acknowledgments: The authors would like to thank two anonymous reviewers for the thorough assessment of the present paper and for their many valuable and helpful suggestions.

Conflicts of Interest: The authors declare no conflict of interest.

\section{References}

1. Kladivko, E.J. Tillage systems and soil ecology. Soil Till. Res. 2001, 61, 61-76. [CrossRef]

2. Holland, J. The environmental consequences of adopting conservation tillage in Europe: Reviewing the evidence. Agric. Ecosyst. Environ. 2004, 103, 1-25. [CrossRef]

3. Bielińska, E.; Mocek-Płóciniak, A. Impact of the Tillage System on the Soil Enzymatic Activity. Arch. Environ. Prot. 2012, 38, 75-82. [CrossRef]

4. Tomkowiak, A.; Starzyk, J.; Kosicka-Dziechciarek, D.; Karwatka, K. The influence of tillage systems on the microbiological conditions of soil. Nauka Przyr. Technol. 2017, 11, 355-364. (In Polish) [CrossRef]

5. Morris, N.L.; Miller, P.C.H.; Orson, J.H.; Froud-Williams, R.J. The adoption of non-inversion till-age systems in the United Kingdom and the agronomic impact on soil, crops and the environment-A review. Soil Till. Res. 2010, 108, 1-15. [CrossRef]

6. Verbruggen, E.; Röling, W.F.M.; Gamper, H.; Kowalchuk, G.A.; Verhoef, H.A.; van der Heijden, M.G.A. Positive effects of organic farming on below-ground mutualists: Large-scale comparison of mycorrhizal fungal communities in agricultural soils. New Phytol. 2010, 186, 968-979. [CrossRef]

7. Smagacz, J. Directions of development of different systems of farming in a change climate. Stud. Raporty IUNG-PIB 2020, 62, 149-167. (In Polish) [CrossRef]

8. Jaskulski, D.; Jaskulska, I. Contemporary Methods and Systems Soil Cultivation in Agricultural Theory and Practice; Centrum Doradztwa Rolniczego w Brinowie: Poznań, Poland, 2016. (In Polish)

9. Drakopoulos, D.; Scholberg, J.M.S.; Lantinga, E.A.; Tittonell, P.A. Influence of reduced tillage and fertilization regime on crop performance and nitrogen utilization of organic potato. Org. Agric. 2016, 6, 75-87. [CrossRef] 
10. Seitz, S.; Goebes, P.; Puerta, V.L.; Pereira, E.I.; Wittwer, R.; Six, J.; Van Der Heijden, M.G.; Scholten, T. Conservation tillage and organic farming reduce soil erosion. Agron. Sustain. Dev. 2018, 39, 4. [CrossRef]

11. Bünemann, E.K.; Bongiorno, G.; Bai, Z.; Creamer, R.E.; De Deyn, G.; de Goede, R.; Fleskens, L.; Geissen, V.; Kuyper, T.W.; Mäder, P.; et al. Soil quality-A critical review. Soil Biol. Biochem. 2018, 120, 105-125. [CrossRef]

12. Melero, S.; Panettieri, M.; Madejón, E.; Gómez Macpherson, H.; Moreno, F.; Murillo, J.M. Implementation of chiselling and mouldboard ploughing in soil after 8 years of no-till management in SW, Spain: Effect on soil quality. Soil Till. Res. 2011, 112, 107-113. [CrossRef]

13. Dębska, B.; Długosz, J.; Piotrowska-Długosz, A.; Banach-Szott, M. The impact of a bio-fertilizer on the soil organic matter status and carbon sequestration-results from a field-scale study. J. Soils Sediments 2016, 16, 2335-2343. [CrossRef]

14. Audette, Y.; Congreves, K.A.; Schneider, K.; Zaro, G.C.; Nunes, A.L.P.; Zhang, H.; Voroney, R.P. The effect of agroecosystem management on the distribution of $C$ functional groups in soil organic matter: A review. Biol. Fertil. Soils 2021, 57, 881-894. [CrossRef] [PubMed]

15. Wang, Y.; Tu, C.; Cheng, L.; Li, C.; Gentry, L.F.; Hoyt, G.D.; Zhang, X.; Hu, S. Long-term impact of farming practices on soil organic carbon and nitrogen pools and microbial biomass and activity. Soil. Till. Res. 2011, 117, 8-16. [CrossRef]

16. Maeder, P.; Fliessbach, A.; Dubois, D.; Gunst, L.; Fried, P.; Niggli, U. Soil Fertility and Biodiversity in Organic Farming. Science 2002, 296, 1694-1697. [CrossRef]

17. Lorenz, K.; Lal, R. Chapter Three-Environmental Impact of Organic Agriculture. In Advances in Agronomy; Sparks, D.L., Ed.; Academic Press: Cambridge, MA, USA, 2016; Volume 139, pp. 99-152.

18. Krauss, M.; Berner, A.; Perrochet, F.; Frei, R.; Niggli, U.; Mäder, P. enhanced soil quality with reduced tillage and solid manures in organic farming-A synthesis of 15 years. Sci. Rep. 2020, 10, 4403. [CrossRef] [PubMed]

19. Osman, K.T. Soil Organic Matter. In Soils; Springer: Dordrech, The Netherlands, 2013; pp. 89-96. [CrossRef]

20. Ghabbour, E.A.; Davies, G.; Misiewicz, T.; Alami, R.A.; Askounis, E.M.; Cuozzo, N.P.; Filice, A.J.; Haskell, J.M.; Moy, A.K.; Roach, A.C.; et al. National Comparison of the Total and Sequestered Organic Matter Contents of Conventional and Organic Farm Soils. Adv. Agron. 2017, 146, 1-35. [CrossRef]

21. Hole, D.G.; Perkins, A.J.; Wilson, J.D.; Alexander, I.H.; Grice, P.V.; Evans, A.D. Does organic farming benefit biodiversity? Biol. Conserv. 2005, 122, 113-130. [CrossRef]

22. Šimon, T.; Javurek, M.; Mikanová, O.; Vach, M. The influence of tillage systems on soil organic matter and soil hydrophobicity. Soil Till. Res. 2009, 105, 44-48. [CrossRef]

23. Haynes, R.J. Labile Organic Matter Fractions as Central Components of the Quality of Agricultural Soils: An Overview. Adv. Agron. 2005, 85, 221-268.

24. Dębska, B.; Drag, M.; Tobiasova, E. Effect of post-harvest residue of maize, rapeseed, and sunflower on humic acids properties in various soils. Pol. J. Environ. Stud. 2012, 21, 603-613.

25. Błońska, E.; Lasota, J.; Zwydak, M. The relationship between soil properties, enzyme activity and land use. For. Res. Pap. 2017, 78, 39-44. [CrossRef]

26. COM 231 Final, Brussels, 22.9.2006. Communication from the Commission to the Council, the European Parliament, the European Economic and Social Committee and the Committee of the Regions Thematic Strategy for Soil Protection. Commission of the European Communities. 2006. Available online: http://eur-lex.europa.eu/legal-content/EN/TXT/PDF/?uri=CELEX: 52006DC0231\&from=EN (accessed on 25 August 2020).

27. Smith, P. Carbon sequestration in croplands: The potential in Europe and the global context. Eur. J. Agron. 2004, 20, 229-236. [CrossRef]

28. Huisz, A.; Sleutel, S.; Toth, T.; Hofman, G.; Neve, S.; Németh, T. Effect of cultivation systems on the distribution of soil organic matter in different fractions. Cereal Res. Commun. 2006, 34, 207-210. [CrossRef]

29. Haddaway, N.R.; Hedlund, K.; Jackson, L.E.; Kätterer, T.; Lugato, E.; Thomsen, I.K.; Jørgensen, H.B.; Isberg, P.-E. How does tillage intensity affect soil organic carbon? A systematic review. Environ. Évid. 2017, 6, 30. [CrossRef]

30. Kononowa, M. Substancje Organiczne Gleby, ich Budowa, Właściwości i Metody Badań [Organic Substances in Soil, They Structure, Characteristics and Analyzing Methods]; Powszechne Wydawnictwo Rolnicze i Leśne (PWRiL): Warsaw, Poland, 1968. (In Polish)

31. Piotrowska, A.; Długosz, J.; Zamorski, R.; Bogdanowicz, P. Changes in some biological and chemical properties of an arable soil treated with the microbial biofertilizer UGmax. Pol. J. Environ. Stud. 2012, 21, 455-463.

32. Januszek, K.; Błońska, E.; Długa, J.; Socha, J. Dehydrogenaze activity of forest soils depend on the assay used. Int. Agrophisics 2015, 29, 47-59. [CrossRef]

33. Nelson, D.W.; Sommers, L.E. Total Carbon, Organic Carbon, and Organic Matter. In Methods of Soil Analysis: Part 3 Chemical Methods; SSSA: Madison, WI, USA, 1996; Volume 5, pp. 961-1010.

34. Dziadowiec, H.; Gonet, S.S. Methodological guide for soil organic matter survey. In Works of Scientific Commissions of Polish Society of Soil Science; Polskie Towarzystwo Geopolityczne (PTG): Kraków, Poland, 1999; Volume 120, 65p. (In Polish)

35. Alef, K.; Nannipieri, P. Enzyme activities. In Methods in Applied Soil Microbiology and Biochemistry; Alef, K., Nannipieri, P., Eds.; Academic Press: Cambridge, MA, USA, 1995.

36. Johnson, J.I.; Temple, K.L. Some variables affecting the measurements of catalase activity in soil. Soil Sci. Soc. Am. Proc. 1964, 28, 207-216. [CrossRef]

37. Pikuła, D. Environmental aspects of managing the organic matter in agriculture. Econ. Reg. Stud. 2015, 8, 98-112. 
38. Du, Z.; Wang, Y.; Gu, R.; Yun, A.; Guo, L.; Han, X.; Li, Y. Changes in soil organic carbon concentration, chemical composition and aggregate stability as influenced by tillage systems in the semi-arid and semi-humid area of North China. Can. J. Soil Sci. 2017, 98, 91-102. [CrossRef]

39. Kinsella, J. The effect of various tillage systems in soil compaction. In Farming for a Better Environment; A White Paper; Soil and Water Conservation Society: Ankeny, IA, USA, 1995; pp. 15-17.

40. Lenart, S.; Perzanowska, A. Impact of no-tillage and conventional tillage on physical separated soil organic matter fraction content. Acta Agrophys. 2013, 20, 595-607. (In Polish)

41. Liu, X.; Herbert, S.J.; Hashemi, A.M.; Zhang, X.; Ding, G. Effects of agricultural management on soil organic matter and carbon transformation-A review. Plant Soil Environ. 2006, 52, 532-543. [CrossRef]

42. Dębska, B. Properties of Humic Substances of Soil Fertilized with Slurry. Ph.D. Thesis, UTA, Bydgoszcz, Poland, 2004. (In Polish).

43. Błońska, E.; Lasota, J.; Piaszczyk, W.; Wiecheć, M.; Klamerus-Iwan, A. The effect of landslide on soil organic carbon stock and biochemical properties of soil. J. Soils Sediments 2017, 18, 2727-2737. [CrossRef]

44. Dannehl, T.; Leithold, G.; Brock, C. The effect of C:N ratios on the fate of carbon from straw and green manure in soil. Eur. J. Soil Sci. 2017, 68, 988-998. [CrossRef]

45. Bengtsson, G.; Bengtson, P.; Månsson, K.F. Gross nitrogen mineralization-, immobilization-, and nitrification rates as a function of soil C/N ratio and microbial activity. Soil Biol. Biochem. 2003, 35, 143-154. [CrossRef]

46. Qi, J.-Y.; Zhang, X.-Z.; Li, S.S.; Virk, A.L.; Wang, X.; Kan, Z.-R.; Zhao, X.; Xiao, X.-P.; Zhang, H.-L. Effects of different tillage practices on the distribution of soil total nitrogen and carbon/nitrogen ratio at different soil depths in a double rice cropping system. Arch. Agron. Soil Sci. 2021, 67, 714-725. [CrossRef]

47. Yuan, B.; Yue, D. Soil Microbial and Enzymatic Activities across a Chronosequence of Chinese Pine Plantation Development on the Loess Plateau of China. Pedosphere 2012, 22, 112. [CrossRef]

48. Yang, L.; Li, T.; Li, F.; Lemcoff, J.H.; Cohen, S. Fertilization regulates soil enzymatic activity and fertility dynamics in a cucumber field. Sci. Hortic. 2008, 116, 21-26. [CrossRef]

49. Acosta-Martínez, V.; Waldrip, H.M. Soil Enzyme Activities as Affected by Manure Types, Application Rates, and Management Practices. In Applied Manure and Nutrient Chemistry for Sustainable Agriculture and Environment; He, Z., Zhang, H., Eds.; Springer: Dordrecht, The Netherlands, 2014. [CrossRef]

50. Gregorich, E.G.; Beare, M.H.; McKim, U.F.; Skjemstad, J.O. Chemical and Biological Characteristics of Physically Uncomplexed Organic Matter. Soil Sci. Soc. Am. J. 2006, 70, 975-985. [CrossRef] 